\title{
PHYLOGENIC ANALYSIS OF THE M GENES OF INFLUENZA VIRUSES ISOLATED FROM SHOREBIRDS
}

\author{
Erdenechimeg Dashzevge ${ }^{1}$, Kunitoshi Imai², Haruko Ogawa ${ }^{2}$ \\ 1- Institute of Veterinary Medicine, Laboratory of Virology, Mongolia \\ 2-Research Center for Animal Hygiene and Food Safety, \\ Obihiro University of Agriculture and Veterinary Medicine
}

\begin{abstract}
Tracheal and cloacal swabs were collected from a total of 195 juvenile shorebirds in the area in 2012 in Eastern Hokkaido, Japan. Viruses showing hemagglutination activity were successfully recovered from 28 bird samples. All viruses were identified as AIV by RT-PCR to detect viral M genes of influenza A virus, and were determined to be H4N7 subtype by RT-PCR for subtyping of AIV. Phylogenic analysis of the matrix (M) genes of 12 strains selected on the basis of their different places and date of surveillance. The $M$ genes of 12 strains belonged to the Eurasian Lineages.
\end{abstract}

KEYWORDS: Shorebirds, Influenza virus, M gene, Phylogenetic analysis

\section{INTRODUCTION}

Avian influenza (AI) caused by influenza A virus of the Orthomyxoviridae and one of the important zoonotic diseases in the world. Influenza A viruses have been isolated from many species, including humans, pigs, horses, mink, felids, marine mammals and a wide range of domestic birds.

The influenza A virus genome consists of eight segments of negative-stranded RNA, which code for 11 proteins. Influenza viruses are classified on the basis of two of these proteins: the hemagglutinin (HA) and neuraminidase (NA) glycoproteins [1].

\section{MATERIALS AND METHODS}

Sample collection

Tracheal and cloacal swabs were collected from a total of 195 juvenile shorebirds between August 31
Sixteen HA subtypes and nine NA subtypes of influenza A viruses have been found in AI viruses (AIVs) which were isolated from wild aquatic birds. Thus, wild birds such as waterfowl and shorebirds were considered as natural reservoirs for influenza $\mathrm{A}$ viruses. AIVs are known to be transmitted by such wild birds in their migration periods. The viruses replicate in the epithelial cells forming crypts in the colon and are shed in fecal materials therefore transmission among birds is mainly by fecal-oral route [3, 5]. Influenza A viruses are in evolutionary stasis in their natural hosts [7] that do not show clinical signs [5].

and September 14 in 2012 around the Komuke and Furen Lakes. After collection, all the samples were kept in virus transport medium (VTM) at $-80^{\circ} \mathrm{C}$ until use. 
Virus isolation

Tracheal and cloacal swab samples were suspended into VTM together. Each of the suspension was centrifuged at $12,00 \mathrm{xg}$ for $10 \mathrm{~min}$ and the supernatant was inoculated into 2 eggs (911 days-old embryonated chicken eggs). The eggs were incubated at $37^{\circ} \mathrm{C}$ for 3 days. After 72 hours of incubation at $37^{\circ} \mathrm{C}$, the inoculated eggs were chilled overnight at $4^{\circ} \mathrm{C}$ and then allontoic fluids were collected and tested for hemagglutination activity. Later, all hemagglutinating agents were identified by hemagglutination inhibition [2] and neuraminidase inhibition [6] tests using the panel of specific anti-sera against reference strains of influenza viruses [4].

RNA extraction, RT-PCR, and nucleotide sequencing

Total RNA was extracted from harvested allantoic fluid by using Isogen reagent according to manufacturer instructions. cDNA was synthesized using Uni 12 primer.

cDNA samples were used for the identification of AIV HA and NA subtyping using 15 sets of $\mathrm{H}$ primers (H1-H15) [9] and 9 sets of $\mathrm{N}$ primers (N1N9) [10].

For the sequencing, cDNA was also synthesized using Uni 12 primer and full-length $\mathrm{M}$ gene was amplified using $\mathrm{M}$ gene-specific primer set (BmM-1 and Bm-M-1027R) [8].

The PCR products were separated by $1 \%$ agarose gel electrophoresis and purified using QIAquick Gel Extraction Kit according to the company`s protocol.
The purified products were used as templates in sequencing reactions using a BigDye terminator ver. 3.1 cycle sequencing kit with the same primers as used for amplification.

Phylogenetic analysis

$\mathrm{M}$ genes of selected isolates, BLAST homology searches were used to retrieve sequences for tree construction. Phylogenetic analysis was based on sequence of $M$ genes (position 1-950bp) of influenza viruses. The Nucleotide sequences were analyzed using GENETYX ver. 10 software (GENETYX Corp., Japan) and compared with other available sequences using BLAST homology searches.

The nucleotide sequences were aligned by Clustal W [9].

The $\mathrm{M}$ gene tree was generated using the Neighbor Joining (NJ) method and bootstrap analysis $(1,000$ replicates) implemented in the Molecular Evolutionary Genetics Analysis program (MEGA 5.1).

\section{RESULTS}

Isolation of influenza $A$ viruses from tracheal and cloacal swabs of shorebirds

Tracheal and cloacal swabs were collected from a total of 195 juvenile shorebirds between August 31 and September 14 in 2012. From these, 28 influenza A isolated viruses were H4N7 subtype virus by RT-PCR (tab.1).

Result summary of AIV subtyping by RT-PCR for the 28 isolates

\begin{tabular}{cccccc}
\hline $\begin{array}{c}\text { Num. of } \\
\text { sample }\end{array}$ & Sample ID & Species & Place & $\begin{array}{c}\text { HA } \\
\text { subtype }\end{array}$ & $\begin{array}{c}\text { NA } \\
\text { subtype }\end{array}$ \\
\hline 1 & 12 EY0012 & red-necked stint & Komuke lake & H4 & N7 \\
2 & 12 EY0029 & red-necked stint & Furen lake & H4 & N7 \\
3 & 12 EY0044 & red-necked stint & Furen lake & H4 & N7 \\
4 & 12 EY0072 & red-necked stint & Komuke lake & H4 & N7 \\
5 & 12 EY0089 & red-necked stint & Komuke lake & H4 & N7 \\
6 & 12 EY0094 & red-necked stint & Komuke lake & H4 & N7 \\
7 & 12 EY0098 & red-necked stint & Komuke lake & H4 & N7 \\
8 & 12 EY0101 & red-necked stint & Komuke lake & H4 & N7 \\
9 & 12 EY0130 & red-necked stint & Furen lake & H4 & N7 \\
10 & 12 EY0131 & red-necked stint & Furen lake & H4 & N7 \\
11 & 12 EY0132 & red-necked stint & Furen lake & H4 & N7 \\
12 & 12 EY0133 & red-necked stint & Furen lake & H4 & N7 \\
13 & 12 EY0134 & red-necked stint & Furen lake & H4 & N7 \\
14 & 12 EY0135 & red-necked stint & Furen lake & H4 & N7
\end{tabular}




\begin{tabular}{|c|c|c|c|c|c|}
\hline 15 & 12EY0142 & red-necked stint & Furen lake & $\mathrm{H} 4$ & N7 \\
\hline 16 & 12EY0144 & red-necked stint & Furen lake & $\mathrm{H} 4$ & N7 \\
\hline 17 & 12EY0146 & red-necked stint & Furen lake & $\mathrm{H} 4$ & N7 \\
\hline 18 & 12EY0154 & red-necked stint & Furen lake & $\mathrm{H} 4$ & N7 \\
\hline 19 & 12EY0169 & red-necked stint & Furen lake & $\mathrm{H} 4$ & N7 \\
\hline 20 & 12EY0170 & red-necked stint & Furen lake & $\mathrm{H} 4$ & N7 \\
\hline 21 & 12EY0172 & red-necked stint & Furen lake & $\mathrm{H} 4$ & N7 \\
\hline 22 & 12EY0173 & red-necked stint & Furen lake & $\mathrm{H} 4$ & N7 \\
\hline 23 & 12EY0174 & red-necked stint & Furen lake & $\mathrm{H} 4$ & N7 \\
\hline 24 & $12 \mathrm{EY} 0178$ & red-necked stint & Furen lake & $\mathrm{H} 4$ & N7 \\
\hline 25 & 12EY0179 & red-necked stint & Furen lake & $\mathrm{H} 4$ & N7 \\
\hline 26 & $12 \mathrm{EY} 0180$ & red-necked stint & Furen lake & $\mathrm{H} 4$ & N7 \\
\hline 27 & 12EY0191 & red-necked stint & Furen lake & $\mathrm{H} 4$ & N7 \\
\hline 28 & 12EY0193 & red-necked stint & Furen lake & $\mathrm{H} 4$ & N7 \\
\hline
\end{tabular}

Phylogenic analysis of $M$ genes of influenza virus isolates

For sequencing, we selected twelve samples, which derived from different places and date of surveillance.

Full-length nucleotide sequences of the $\mathrm{M}$ gene were analyzed for all 12 isolates, and it was found that those isolates are $100 \%$ homologous in the $\mathrm{M}$ gene.

The BLAST homology searching showed that the $\mathrm{M}$ gene of all 12 isolates was close to $\mathrm{A} /$ duck/Jiangsu/26/2004(H3N2) in both nucleotide sequence homology $(97.38 \%)$ and amino acid $(99.6 \%)$. Furthermore, phylogenic analysis showed that $\mathrm{M}$ genes from 12 isolates belonged to the Eurasian lineage. The result and phylogenic analysis were shown in Figure 1. 
Fig.1. Phylogenetic tree of influenza A virus $M$ genes. The phylogenetic tree was constructed using Neighbor Joining (NJ) method (1,000 replicates) and Mega 5.1 software. The strains isolated in this study are highlighted by triangles.

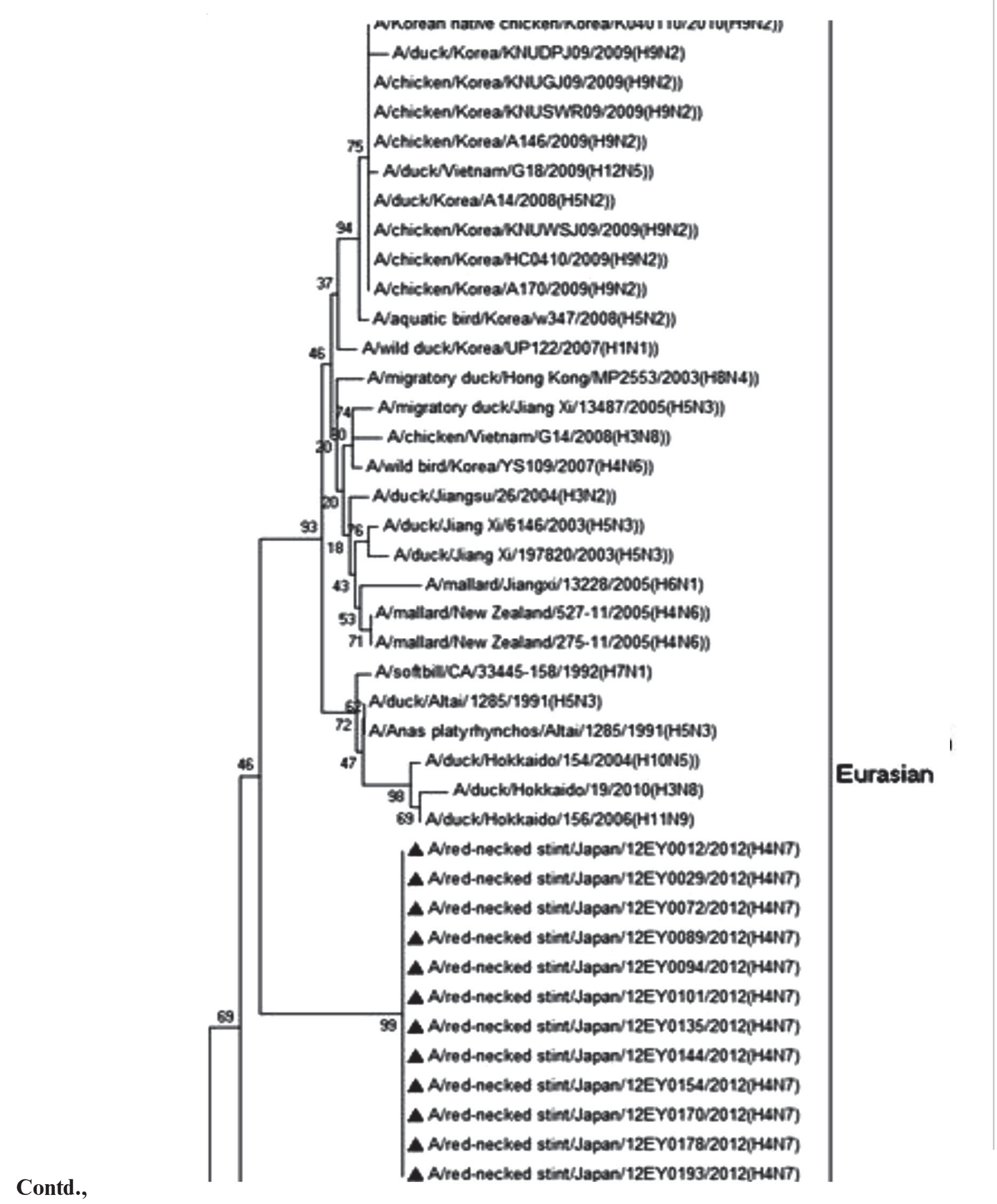




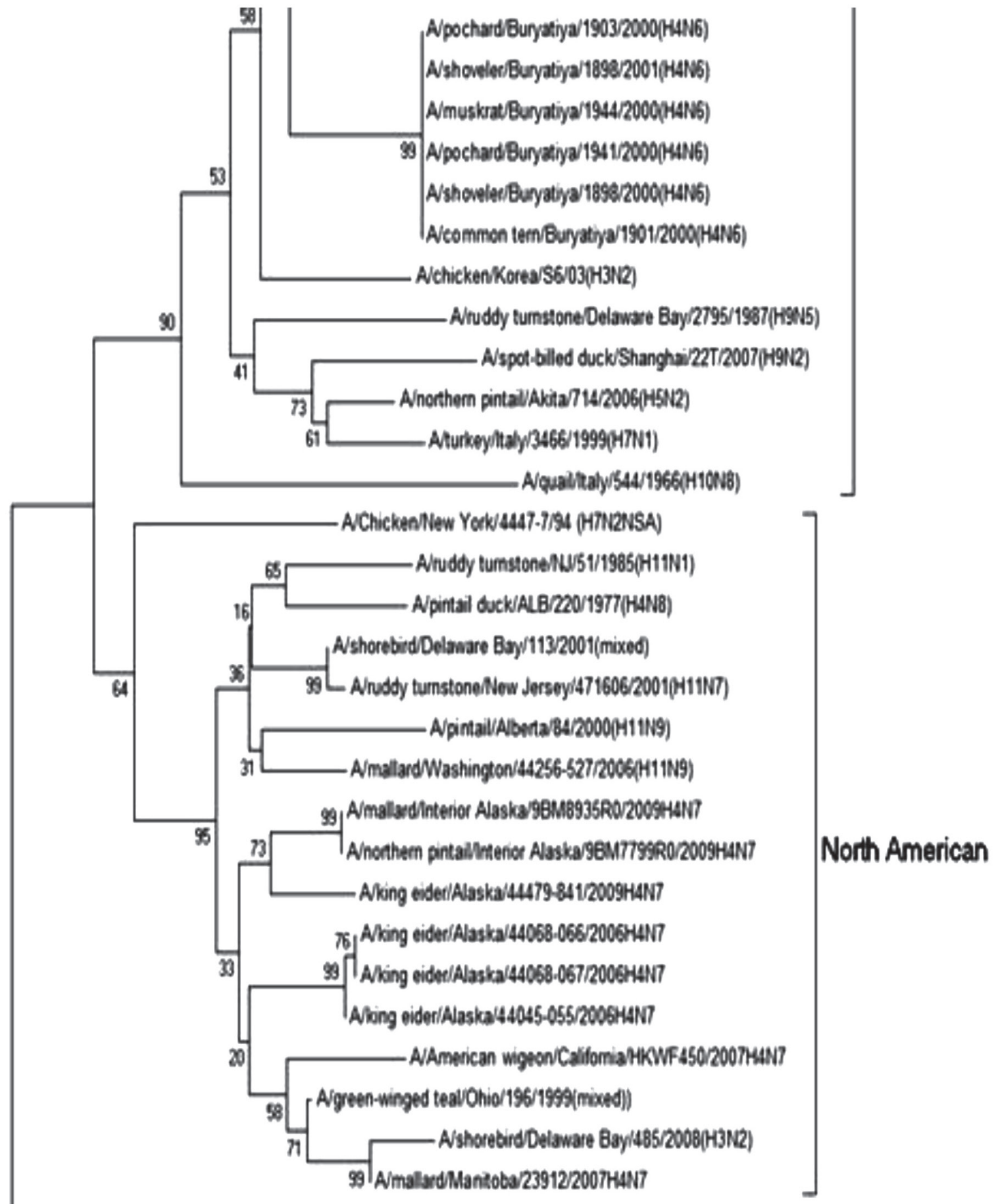

Apetin ductuCaliforniaP30/2006/HAN2)

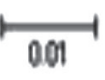

\section{DISCUSSION}

We isolated 28 strains of the H4N7 subtype virus from red-necked stints in August of 2012. This is the first isolation of the H4N7 subtype virus in Japan. The $\mathrm{M}$ gene of all the 12 isolates analyzed was close to A/duck/Jiangsu/26/2004(H3N2) in both nucleotide sequence homology $(97.38 \%)$ and amino acid (99.6\%).
The result indicated that $\mathrm{M}$ genes of $\mathrm{H} 4 \mathrm{~N} 7$ isolates are phylogenetically grouped with Eurasian lineage viruses.

All of strains of the H4N7 subtype virus were isolated from red-necked stints. Red-necked stints are migratory birds. Many migratory birds are known to perform regular long-distance migrations [1], thereby potentially distributing LPAI viruses between countries or even 
continents. Birds breeding in one geographic region often follow similar migratory flyways. Japan is included in the East Asian-Australian flyway, which covers part of eastern Siberia, western Alaska, southern to eastern Asia and Australia. Therefore, it is possible that virusinfected birds can transmit their pathogens to other populations that subsequently may bring the viruses to new areas.

\section{REFERENCES}

1. Bjorn Olsen et al 2006. Global Patterns of Influenza A Virus in Wild Birds. Science 312, 384.

2. J.L. Sever. J. Immunol. 88, 320 (1962)

3. R.G. Webster, W.J. Bean, O.T. Gorman, T.M. Chambers, Y.Kawaoka, Microbiol. Rev.56, 152 (1992)

4. H. Kida, R. Yanagawa. Zentralbl. Bakteriol. 244, 135 (1979)

of the neuraminidase of avian influenza viruses. J. Virol. Methods 155, 193-198.
5. H. Kida, R. Yanagawa, Y. Matsuoka, Infect. Immun. 30, 547 (1980) M. Aymard-Henry, M.T. Coleman, W.R. Dowdle, W.G. Laver, G.C. Schild, R.G. Webster, Bull. World Health Organ. 48, 199 (1973)

6. O.T. Gorman, WJ. Bean, R.G. Webster, R. Deibel, B. Turner, Bull. World Health Organ. 63, 711 (1985)

7. E. Hoffmann, J. Stech, Y. Guan, R.G. Webster, D.R. Perez, Arch. Virol. 146, 2275 (2001). Doi:10.1007/s007050170002

8. J.D. Thompson, D.G. Higgins, T.J. Gibson, Nucleic Acids Res. 22, 4673 (1994). Doi:10.1093/nar/22.22.4673

9. Lee, M.-S., Chang, P.-C., Shein, J.-H., 2001. Identification and subtyping of avian influenza viruses by reverse transcriptionPCR. J. Virol. Methods 97, 13-22.

10. Qiu, B-F., Liu, W-J., Peng, D-X et al 2009. A reverse transcription- PCR for subtyping 